\title{
My Talk at the ASIL: What Is New Thinking in International Law
}

\section{Citation}

David Kennedy, My Talk at the ASIL: What Is New Thinking in International Law, 94 Am. Soc'y Int'l L. Proc. 104 (2000).

\section{Published Version}

http://www.jstor.org/stable/25659366

\section{Permanent link}

http://nrs.harvard.edu/urn-3:HUL.InstRepos:16076123

\section{Terms of Use}

This article was downloaded from Harvard University's DASH repository, and is made available under the terms and conditions applicable to Other Posted Material, as set forth at http:// nrs.harvard.edu/urn-3:HUL.InstRepos:dash.current.terms-of-use\#LAA

\section{Share Your Story}

The Harvard community has made this article openly available.

Please share how this access benefits you. Submit a story.

\section{Accessibility}




\title{
MY TALK AT THE ASIL: WHAT IS NEW THINKING IN INTERNATIONAL LAW?
}

\author{
by David Kennedy
}

What is "new thinking" in international law? How does a discipline like this one innovate? I thought I would speak today about the ways in which international law has conventionally renewed itself by transforming its disciplinary vernacular.

\section{THINKING ABOUT INTERNATIONAL LAW AS A PROFESSIONAL DISCIPLINE}

International law is often defined as a set of rules, doctrines, and institutions-perhaps as "the law which governs relations among states." Although this can be helpful, I am more interested in understanding international law as a lived professional practice, as an intellectual discipline, as the culture developed by international lawyers to speak about what they see as the political and social world around them.

I define international law as a group of people sharing professional tools and expertise, as well as a sensibility, viewpoint, and mission. Their disciplinary consciousness or lexicon is composed of typical problems, a stock of understood solutions, a vocabulary for evaluating new ideas, a sense about their own history and a way of looking at the world. They launch projects of criticism and reform within and against this professional vocabulary. Of course their shared professional sensibility may differ across time, just as international lawyers in different countries may have rather different professional preoccupations or priorities. Almost as a byproduct of their professional work, relatively stylized modes of criticism and reform emerge which express what we interpret as a relatively continuous disciplinary character or style. Over the life of a discipline, common interpretive formulas or traditions develop-what we often think of as "schools of thought"-which can remain stable for a long time, just as they can unravel.

A common disciplinary vocabulary like this can extend and reinforce the profession's accumulated knowledge about what works and what doesn't, which may be all to the good. But, of course, a disciplinary vocabulary can also have limitations, characteristic blind spots and biases. A professional vocabulary can have unacknowledged bad effects when it legitimates, explains away, apologizes for or simply distracts professional attention from injustice. Like other such professional vocabularies, the routine rhetorical practices of international lawyers can place those who use them in bad faith, uncomfortably stretched between what they in some sense know to be true or possible and what they can find words for at that moment within their professional vocabulary.

\section{MAPPING A PROFESSIONAL VOCABULARY}

There are no doubt lots of ways to map the vocabulary or expertise of a discipline such as international law. One sort of map would stress the worldviews of participants in the field: What do they see? What do they worry about? What do they remember? How do they understand their history? Where do they look for disciplinary inspiration? What do they want? In my own past work, I have tried to compare international lawyers to professionals in other related fields in precisely this sense, using this little map:

\footnotetext{
• Henry Shattuck Professor of Law, Harvard University Law School, Cambridge, MA.
} 
PUBLIC INTERNATIONAL LAW:

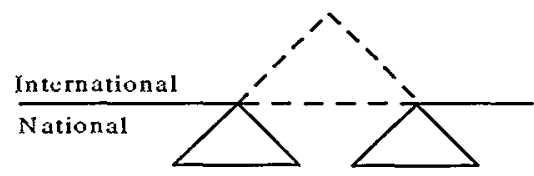

Project: governance

INTERNATIONAL ECONONIC LAW:

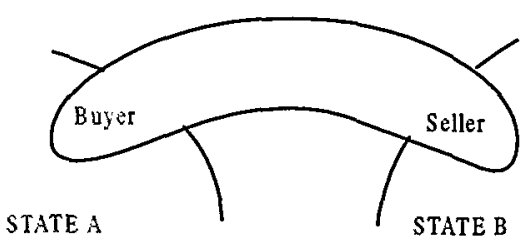

Project: trade

COMPARATIVE LAW:

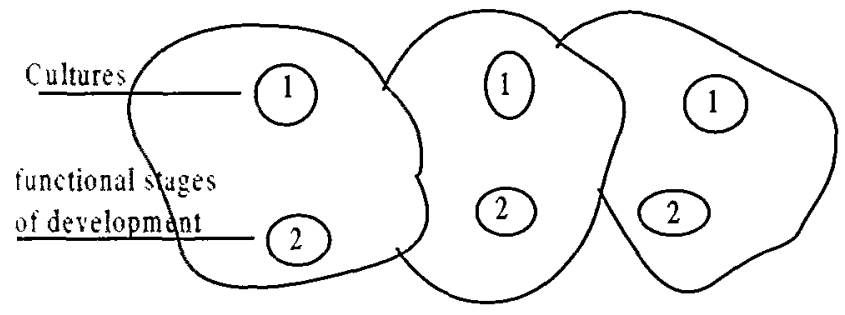

Project: understanding

We can make a quick comparison:

Public international lawyers look out at the world and see states, they worry about how law will be possible among sovereigns, they remember wars, understand their history as progress from sovereign autonomy to international community, from formal rules to pragmatic principles and institutions, look to political science for inspiration, and they want improved global governance.

International economic lawyers look out and see buyers and sellers hoping to trade, they worry about the myriad risks of transacting internationally, particularly those caused by governments, they remember the Great Depression and understand their history as progress toward ever lower tariff barriers and an ever more flexible legal/institutional structure for trade bar- 
gaining, they look to economics for disciplinary inspiration and they want an ever more reliable free trade regime.

Comparative law professionals look out at the world and see different legal cultures, comprised of national systems at different functional stages of development, they worry about professional parochialism and understand their history as a march toward greater knowledge about the influences, similarities, and differences among cultures and developmental phases, they look to sociology or anthropology for inspiration, eschew any direct hand in governance and they want greater understanding.

This sort of map may be helpful in identifying the professional blind spots and biases born of specialization. To understand disciplinary change, of course, we need a map that is far more sensitive to relations among disciplines in a particular place, and to the relationship between people working within the field and the broader intellectual, political and social terrain of their society. I have tried to make maps of this sort, intellectual sociologies if you like-they tend to get really complex really fast, and I won't attempt one here this morning.

Yet another sort of map, however, more important to the story of disciplinary renewal I would like to tell today, focuses on developments within the field's vocabulary of disputation. This sort of map requires some historical investigation, and enough disciplinary continuity to trace changes in a common vocabulary. In mapping the history of international law's vocabulary, two things have struck me.

I have persistently been struck by the reappearance of classic debates, tensions and ambivalences that show no sign of resolution. At the same time, for all the diversity in political projects and ideologies represented in the field, for more than a hundred years international lawyers have shared a few basic commitments that I would describe as "cosmopolitan," "liberal" and "humanitarian." It is impossible to evaluate the profession's century of achievement without coming to terms with the virtues and vices of both professional equivocation and the broader liberal cosmopolitan tradition to which this profession has been committed.

The ambivalence: It is customary in talking about the intellectual history of a legal field to treat doctrinal conclusions and institutional outcomes as slowly establishing a corpus of best practices or ruling precedents. There will always be paths not taken as well as remaining questions, but the point of the exercise is to document whatever clarity there might be about the rules in place, and about the ups and downs of doctrinal clarity and institutional competence that have led to this point, on the broad understanding that the field is learning, maturing, coming into its own.

International legal histories of this type have generated a number of common assumptions about the field: that international law is dominantly about states and sovereignty; that its dominant interpretive method is rather formal compared to that of other fields; that consent lies at the heart of its binding force. That "it" is law, rather than politics, and international, rather than local. That its rules are public, rather than private. That the field has progressed, just as international society has progressed, from a period of sovereign autonomy to one of international community, from a time of rules to a period of principles, from a law of doctrines to one of institutions, from governments roped together by treaties to an open-ended process of global governance, from a formal legal method to something more functional, modern and pragmatic.

I am always struck by the extent to which this is not at all the whole story. For more than a century, international lawyers have imagined each new moment as the overcoming of sovereignty, formalism, autonomy, politics, and the coming into being of law, pragmatism and international community. More than a hundred years ago, they were already proclaiming the arrival of institutions, pragmatism, community, globalization. At the same time, that which has been thought finally overcome continually returns, not only as an evil foe but as a newly attractive reform. We need only think of the resurgence of formal attitudes toward law, in doctrines about territory (uti possedetis, for example) or in the increasing legalization of the world trading system, to realize that the triumph of antiformalism has been neither rapid nor complete. Indeed, it would be more accurate to say that the discipline sustains interest in these 
propositions with the deepest ambivalence.

Almost every basic doctrinal proposition in the field is now conceived in at least two voices-a voice of stability, associated vaguely with the past, and an updated or renewing or reform $\backslash$ ision which is more complex, relevant, up-to-date. Looking back, we see a field with a double consciousness about its own materials. There are rules and exceptions; classic positons and new thinking, formal definitions and pragmatic solutions. The discipline is both tenaciously attached to the classic definition of international law as "law among sovereign states" and full of denunciations of international law's fetish-like attachment to states and to "sovereignty."

As a result, it is far more useful in reconstructing the field's intellectual history to identify the debates that continually preoccupy the field, rather than the stockpile of temporary and partial resolutions that litter the disciplinary landscape, and to focus on the voice of the professional which can bring these contradictory tendencies into harmony, at least temporarily, and can reframe particular choices as contributions to disciplinary progress.

The common vision: When international lawyers look at the world, it is self-evident to them that we have plenty of politics, but only very little law. The idea that we have plenty of law, a kudzu of procedures and norms beneath which only the most tenuous political culture cin survive, is simply not on the table. Let me take three key elements in this common vision in turn.

Crsmopolitanism: A hundred years ago this was termed l'esprit d'internationalité. In the $1920 \mathrm{~s}$ and $1930 \mathrm{~s}$, as again in the 1950s, it was reflected in an increasingly federalist interpretation of international organizations, and today it is visible as enthusiasm about "global governance." The idea here is commitment to the general, the global-as opposed to the particular, the local, the cultural. As cosmopolitans, international lawyers are more concerned with the level at which solutions emerge or governance proceeds than with the details of those solunons or the distributive consequences of that governance. Where they govern, they aspire to do so with clean hands, detached from the messy business of arbitrating among political groups. This is an arm s-length government of adjudication and consensual dispute resolution.

Liheralism: The international legal vocabulary imports the problematic of liberal political theory into international affairs. The international lawyer sees a world of separate, autonomous communities ("states") struggling to relate to a hypothetical "world community," which they can join while remaining free. International lawyers construct their field around the philosophical question How is governance possible among free entities in a community? Since relations among tates "are" political, and law "is" a national creation of the sovereign, it is difficult to build an international law. They experience this worry as both a philosophical problem to solve (How can there be law among sovereigns?) and as a practical challenge (What should we do next to strengthen law among states?). Like domestic liberal political theory, international law often explain the compatibility of freedom and constraint in contractual terms. At times, the international legal order has seemed a Benthamite machine for maximizing the happiness of the greatest number, at others, a Kantian vehicle for protection of fundamental rights.

Liberalism has plenty of associations, and international lawyers have been drawn to all of them at one time or another, a left-of-center faith in the humanitarian potential of federal and universal government, a right-of-center belief in mercantilism and the pacific consequences of commercial freedom, a centrist commitment to technocratic and rational government. They have typically advocated moderate or intermediate solutions to problems of international governance, have emphasized possible harmony of interests, rational governing techniques, the need to "balance" among opposed considerations, moderation in social reform, self-determination and participation by social groups in decision making.

Humanism: International lawyers have seen themselves as an avant-garde for peace, for rocial goals and humanitarian causes. The keys here are pragmatism, humanitarianism, functionalism, universalism. International law, they feel, stands with peace, prosperity, and a 
forward-looking and pluralist global community, while "politics" is associated with war, the collapse of commerce, a primitive parochialism. They stress international law's social and emancipatory potential, its ability to express and further universal human needs/wants/natures/ functions, rather than its potential for defending the aggressor or miscreant. They advocated arbitration to replace war, institutions for dispute resolution and rationalist machinery for collective security-a benevolent and civilizing global governance system. In this they have been ardent reformers, of their discipline and of the world.

So far so good. But we also need to explore, to map if you like, the vocabulary with which international lawyers have expressed these ambivalences and articulated this common vision: the vocabulary of their expertise, in which they express, formulate, and defend reforms. It is not surprising that as international lawyers have worked to build a legal system outside the state, they have pursued issues that parallel the traditional forms of domestic law: legislation, administration and adjudication. Their efforts to do this might be arranged on a spectrum from direct efforts to reproduce domestic legal forms and institutions among states to more indirect efforts either to build looser "functional equivalents" for domestic legal institutions or to reinterpret the conditions of statecraft as a more "primitive" version of national law.

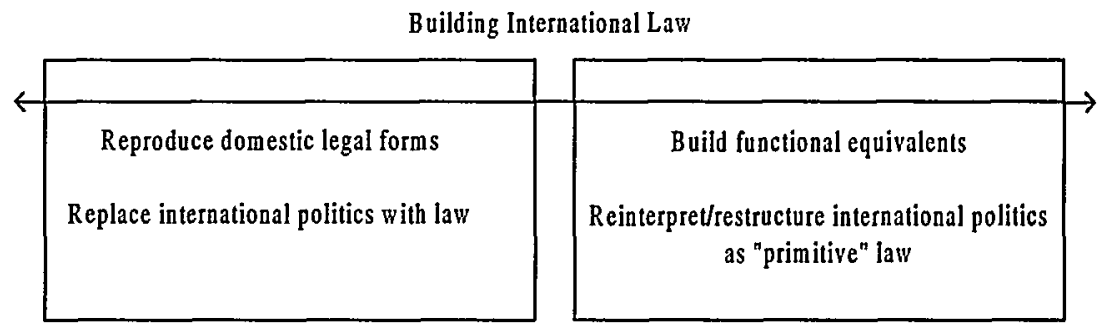

International lawyers have proposed a large number of different techniques to build international law across this spectrum, which cover all three types of legal/political authority: legislative, administrative, and adjudicative. The debates in each of these domains might also be arranged along a spectrum.

\section{Legislation}

Here we find work on "sources of law," on the best modes of legislation or codification, on the relative merit of treaty and custom, or of rules and principles, and on the relationship between norm generation and enforcement. The spectrum would run from efforts to establish an international legislature with binding powers or to codify an international common law through to softer efforts to expand the domain of stable intersovereign expectations and habits that "function" as norms.

Building International Legislative Capacity

\begin{tabular}{|c|c|}
\hline Formal codification of law \\
Treaty \\
Rules / Rights \\
Norm generation \\
$\begin{array}{c}\text { Legislature with binding powers } \\
\text { Unanimity voting - one state one vote }\end{array}$
\end{tabular}$\quad \begin{gathered}\text { Stable intersovereign expectations } \\
\text { Custom - "soft law" } \\
\text { Principles } \\
\text { Norm enforcement } \\
\text { Plenary with political authority } \\
\text { Consensus or weighted voting }\end{gathered}$

\section{Administration}

International lawyers (often in more or less strained partnership with the fields of "inter- 
national institutions" and political science) have worked on the constitutional structure for international bureaucracy, on forms of leadership, on the construction, reform, coordination and control of an international civil service. The enforcement arm for international law might also be either a formal equivalent of the domestic state or a more primitive and decentralized functional equivalent based on the mobilization of shame and political pressure within the "international community."

Building An Effective International Administration

\begin{tabular}{|c|c|}
\hline $\begin{array}{c}\text { Institutions } \\
\text { Legal Personality } \\
\text { Strong and autonomous civil service } \\
\text { Internationdl law enforced through } \\
\text { biuding adjudication with penalties } \\
\text { Collectively imposed sanctions } \\
\text { Focus: Intergosernmental Institutions }\end{array}$ & $\begin{array}{c}\text { Organizations } \\
\text { The instruments of members } \\
\text { Secondment / Civil servants as clerks } \\
\text { Informal enforcement: information } \\
\text { sharing to mobilize com munity shame } \\
\text { Rely on domestic institutions } \\
\text { Focus: NG0s and civil society }\end{array}$ \\
\hline
\end{tabular}

\section{Adjudication}

We find work structuring an international adjudicative process-rules about jurisdiction, enforcement of decisions, etc. International lawyers speculate about what law might offer to the peaceful settlement of disputes, or about the relative merits of adjudication, arbitration, conciliation and other dispute settlement formats.

Strengthening the International Judiciary

\begin{tabular}{|c|c|}
\hline & \\
\hline Court based adjudication & Mediation / conciliation / good offices \\
\hline Conventul jurisdiction / binding decisions & Expansive jurisdiction / non binding \\
\hline $\begin{array}{l}\text { Procedural rules deduced from nature of } \\
\text { sorereingty }\end{array}$ & $\begin{array}{l}\text { Procedural rules deduced from nature of } \\
\text { international community }\end{array}$ \\
\hline
\end{tabular}

The terms within which these choices are debated are surprisingly consistent across the last century, and the pattern in these debates is at odds with the idea that the choices are either pragmatic (what will work best in this context) or responsive to immediate historical developments (what will best catch this historical wave). To defend choices in the left-hand columns, international lawyers stress the importance of sovereignty, at least as a current reality, as well as the need to root international law firmly in the consent of sovereigns, and the importance of establishing an international law distinct from political calculation. In defending choices in the right-hand columns, international lawyers stress the desirability of sneaking up on sovereignty. An international law more embedded in its political context, in this view, will be more likely to dislodge sovereignty and will express more adequately the will of the current and future "international community." 
Arguing For and Against Specific Reform Projects

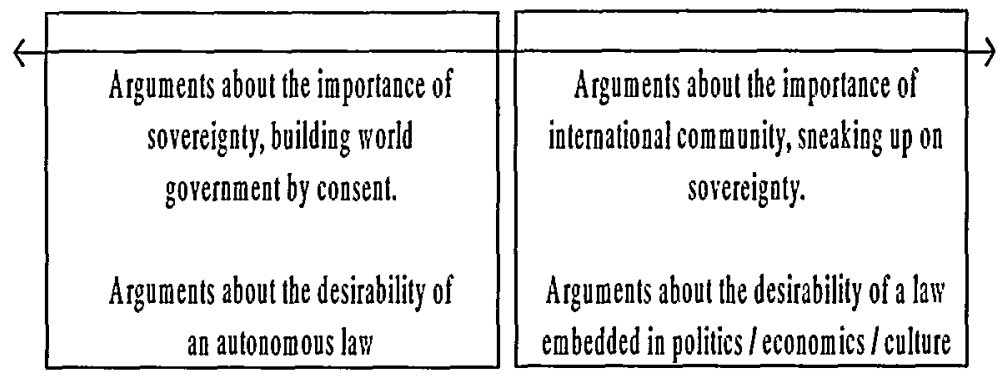

One point about this argumentative practice needs emphasis at this stage. International lawyers tend to defend and criticize relatively modest reforms-very minor movements along the spectrum - in extreme and hyperbolic terms. Think of legislative mechanisms, arrayed from very formal consent-based treaties to the quasi-legislative or persuasive force of "nonbinding" agreements. Somewhere along this spectrum, we would find people proposing to strengthen the persuasive power of, say, UN General Assembly recommendations, and people opposed to this idea. This quite modest alteration in the overall scheme of sources, as it is debated, seems to implicate all of the arguments for an embedded law, and all of those for an autonomous law. Proponents of one or the other side characterize the proposals, however "close" they might lie to one another on the spectrum, as implicating all the strengthes and weaknesses of the opposite extreme.

The result is, as one might expect, often a great tempest in a teapot, as well as a tendency to disciplinary sectarianism. It would not be too much simply to describe the international lawyer's professional vocabulary as a stockpile of arguments for the hyperbolic defense of modest reforms. But it is nevertheless an exceedingly complex argumentative vocabularythere are numerous ways of characterizing different reform projects along argumentative trajectories of this sort.

It is quite common, for example, to debate particular reform proposals by arguing about the appropriate boundaries for the discipline. How autonomous should international law be from politics? Is it stronger when it embraces or shuns the political? The most basic mode of arguing for or against a given institutional or doctrinal possibility, whether macro ("norm building or administration?") or micro ("should uti possedetis trump self-determination in this case?") is to cast the alternatives as bringing law closer to or further from politics, and then treating the question as implicating the appropriate boundaries of the field. At this level, the arguments for and against a more political international law are intensely familiar and easily presented as a story about progress. Either international law has been too far from politics and must move closer to become effective, or it has become dangerously intermingled with politics and must assert its autonomy in order to remain potent. Pretty much any choice from the left columns can be defended, relative to its partner on the right-hand side, by stressing the need to keep law pure of politics, just as any choice on the right side can seem a vehicle for merging international law more fully into the political context.

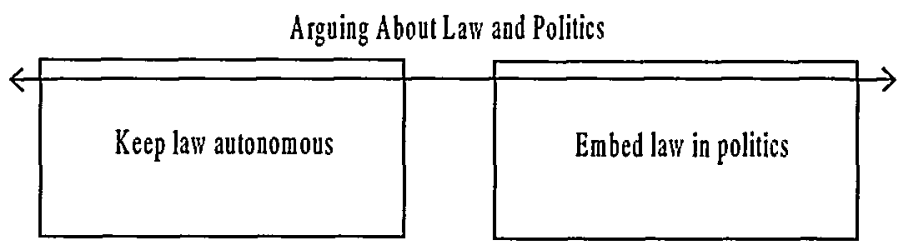


A very similar argumentative structure has developed around a series of boundary issues. For example, how closely should a public law external to states be modeled on national law? Should we be seeking to reproduce the functions of national public law or the forms of national private law or both?

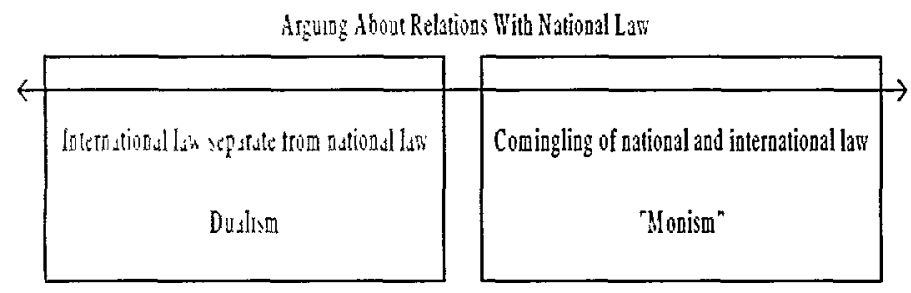

At one level, international law is not concerned with real people-it is concerned with real problems perhaps, but its agents, subjects and objects are "states." Still, in pursuing this disciplinary identity, the field has been perennially enmeshed in relations with social movements of various sorts: the peace movement, the women's movement, the environmental movement, the human rights movement, the labor movement, the indigenous people's movement. But how far should this go?

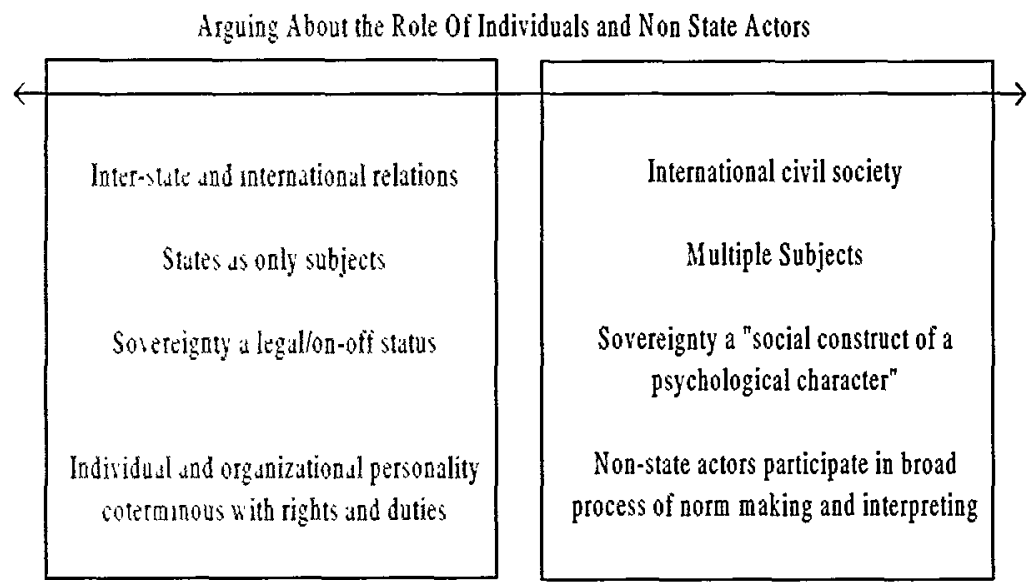

International law has seen itself as "public" law, about governing. But there is also a private international legal order, often deeply enmeshed in national law. We find a great deal of work on the "public" nature of international law and on the field's relations with the worlds of economics, the market, mercantilism, trade policy: in the left column, a sharply differentiated public and private law; in the right, a flexible governance partnership with economic law and institutions.

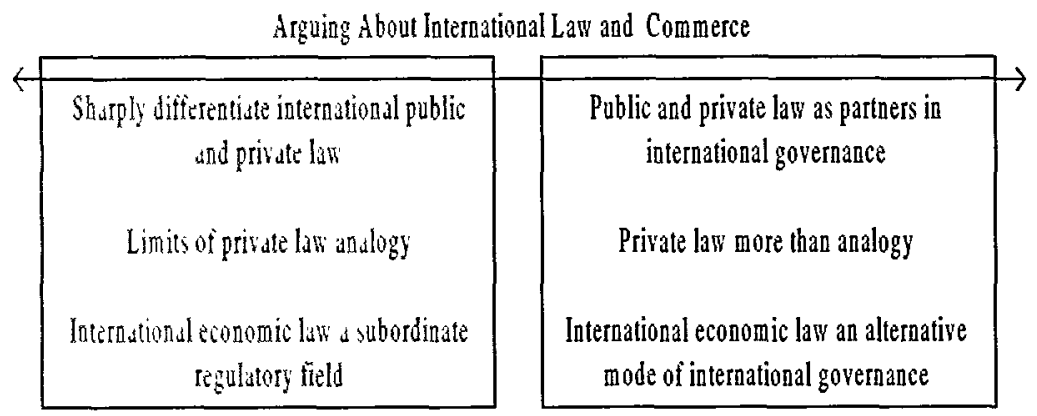


You get the idea. But there is no stopping here-we might continue this list and speak about relations with nationalism, with religion, with values, with the periphery, and so on.

\begin{tabular}{|c|c|c|}
\hline \multicolumn{2}{|c|}{ Arguing A bout Nationalism } \\
\hline Nationalism a local problem & & A more variable international law \\
Self-determination & Nationalism an international problem \\
Uti posseditis & Minority protection \\
Succession & Succession \\
& More fluid arrangements \\
\hline
\end{tabular}

Arguing About the Role of the Periphery

$\left.\begin{array}{|c|c|}\hline \text { Universal humanism } \\ \text { Assimilation } & \text { Local / regional cultures } \\ \text { Encourage participation } & \text { Normative flexibility } \\ \text { Substantive engagement } \\ \text { Formal equality } \\ \text { Terrorist as outlaw } \\ \text { On/Off approach to insurgents }\end{array}\right]$

Arguing About Religion and Values

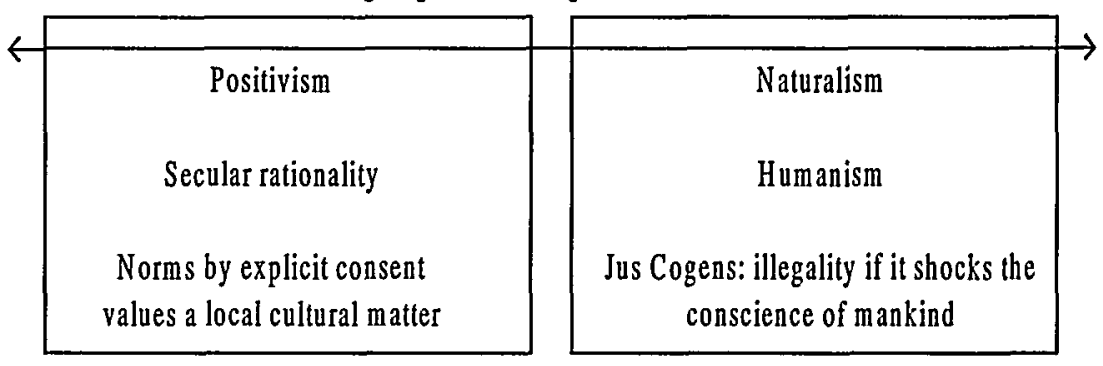

\section{HOW CAN WE ORGANIZE THESE ARGUMENTS?}

In arguing about the relations between international law and neighboring social spheres and in proposing or opposing particular institutional forms, international lawyers return repeatedly to two basic axes of philosophical disputation, each with its own well-developed vocabulary: the relationship that law should seek to strike between an international community and sovereign autonomy, and the most effective balance between a more formal and less formal law. 


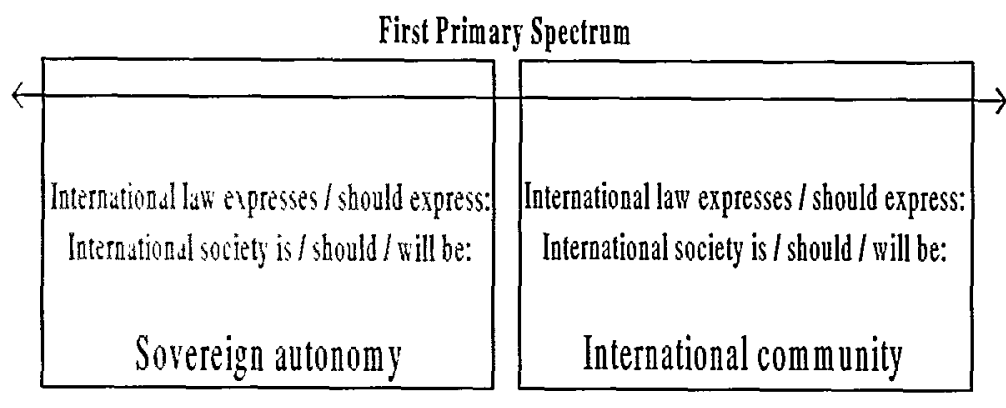

\begin{tabular}{|c|c|}
\hline $\begin{array}{c}\text { Shurp distinctions law / politics } \\
\text { or mutional / international } \\
\text { Autonomous law based in consent } \\
\text { Oblective and scientific }\end{array}$ & $\begin{array}{c}\text { Soft distinctions law / politics } \\
\text { or national / international } \\
\text { Embedded law based in value } \\
\text { Subjective judgment }\end{array}$ \\
\hline
\end{tabular}

There is a relationship between these two primary vocabularies. As a starting point, we could say that international lawyers have predominantly associated sovereign autonomy with formal law and international community with antiformal law. They have tended to see movement from left to right on these spectra as progress-to think that we move from autonomy to community as we move from formal to pragmatic law. There has also always been a less often voiced counternarrative, however. From late in the nineteenth century, international lawyers in a variety of places have stressed the centrality of the nation to international law's project, and seen movement to perfect the nation-in Italy, in Germany, but also through extension of the national form and the principle of national equality to extra-European societies in Asia and elsewhere, through self-determination, and eventually decolonization-as progress from the more integrated, if haphazard and hegemonic, international system of the past.

In the development of this story, the terms that are thought to convey differences along these continua may differ over time. At one point, the difference seemed well captured by the choice between rules, whether codified by treaty or by custom, and "general principles of law" or the new category of "soft law." At a later moment, after inquiry into the "sources of law" no longer seemed so foundational, the entire effort to generate norms-including both rules and principles-seemed to epitomize the left column, while international lawyers drawn to a less formal international law focused more on matters of policy, asking what arrangement fulfilled a desired political or institutional "function" best, rather than what arrangement was normatively persuasive. This sort of transformation has been common in international law across the century. We might mark this sort of change like this: 


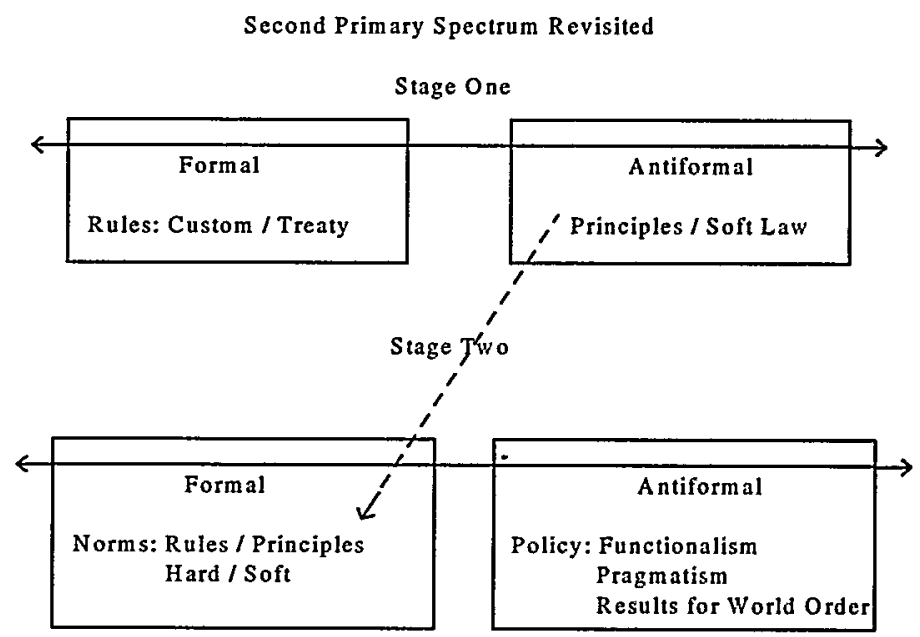

This sort of transformation is possible because the terms that illustrate the spectrum are capable of being interpreted to lie in various places along it relative to one another. At a more theoretical level, for some time the general difference between formal and informal attitudes about international law seemed captured by the difference between "positivism" and "naturalism." After theories about the nature of international legal obligation came to seem less important than theories about how international law could be most effective, those drawn to both naturalism and positivism seemed relatively more formal than those adopting a "pragmatic" or "functional" approach.

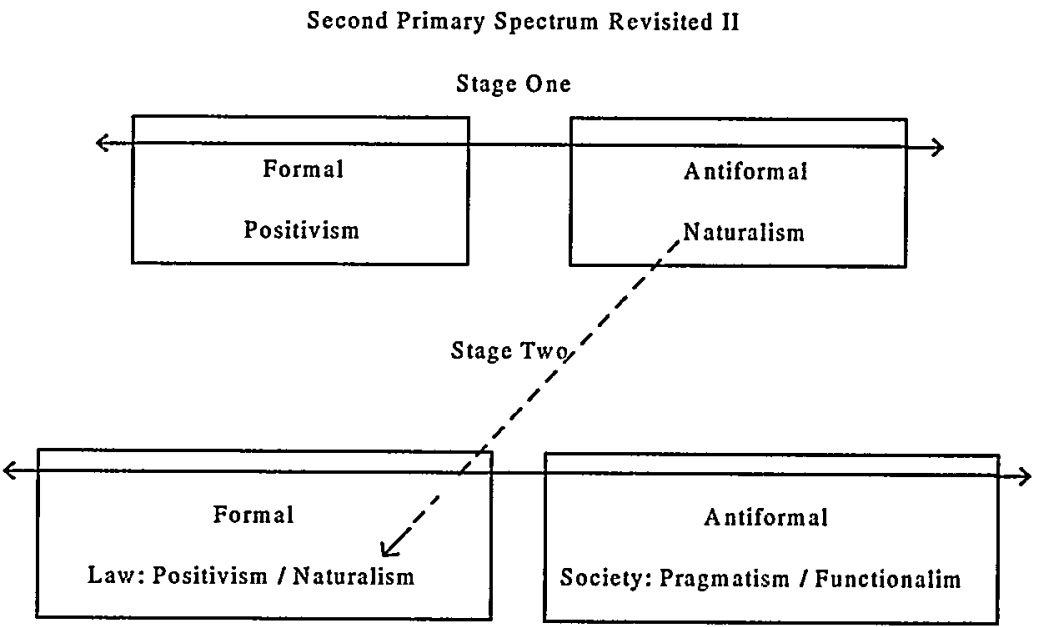

As international lawyers have argued about various reforms, it is unusual to find anyone close to the extreme end of either spectrum. If you thought the situation was and always would remain one of complete sovereign autonomy, it would be difficult to imagine a role for international law. If you thought the international community had fully eliminated the sovereign state, it would be difficult to understand how the law that remained could be seen as "international." Being an international lawyer means seeking to bring autonomous sovereigns into community. Most everyone acknowledges the importance of both rules and broader principles; everyone sees a situation for both sovereign autonomy and international community. No 
International lawyer imagines law in mechanical terms, just as no international lawyer sees it smply as an expression of natural values or religious principles.

If you put these two things together-no international lawyer is comfortable at the extremes and particular positions can be reinterpreted to lie at different points on a spectrum relative to one another--the result is a very puzzling interpretive practice. Assessing positions on these spectra in progressive or ethical terms runs one into a sort of Zeno's paradox. Since everyone is situated in some way between the extremes, one may approach-without ever quite reaching-rules or institutions that clearly signal the presence of an international community; one may downplay, but never quite eliminate, rules or institutions that seem to express the imperatives of legal form. The effort to frame a choice between two arrangements-say, custom and treaty -in terms that implicate the larger issues of sovereign autonomy and internationil community, or a formal and an antiformal international law, runs into the difficulty that custom and treaty are often able to be recharacterized to lie elsewhere on the spectrum. Just when one has railed against custom for entrenching the politics of the past and defended treaties for their ability to legislate with the times, custom can seem altogether flexible and modern compared to the requirement that states reach formal consent before anything can be done - a formula guaranteed to produce vague political compromises rather than workable rules. It is a common experience that no sooner is a more functionalist/community-orlented solution reached than it finds itself open to criticism as emblematic of the formal order wedded to sovereignty which must be overcome. It is in this sense that we might say that there is a deep ambivalence about both the direction progress takes and the terms with which it is marked.

Nevertheless, doctrinal and institutional reforms continue to be evaluated in terms of these broad arguments about their significance for the system as a whole. It is surprising how rarely international lawyers argue for particular projects in terms of the specific distributional or strategic consequences for particular groups. At the same time, these general terms are understood by almost all those who use them not to be entirely persuasive or nearly as dispositive as the arguments made in using them would suggest.

\section{SCHOOLS OF THOUGHT IN INTERNATIONAL LAW}

Since a wide range of large and small choices are framed to present these boundary issues, it comes as no surprise that international lawyers have repeatedly reflected on them in theoretical terms. To be a "school of thought" in international law means to have a relatively stable position on these broad theoretical questions. No one thinks these will ultimately be defensible positions. On the contrary, people in the field imagine that virtually all the possible povitions are already on the table and have been found inadequate. Nevertheless, we are familiar with international lawyers who see autonomous sovereigns behind every bush, and others who see everywhere a community at work. Likewise, we know those who think in terms of rules and worry about defending law's autonomy from subjective and political influences, and those who think about principles and policies and worry about ensuring law's links with its context.

Understanding a school of thought in the field means understanding where on the continuum of different answers-all understood to be bad answers-a given group gravitates. Do they tend to think of law in formal and autonomous terms? Do they emphasize that law can only be built among sovereigns by consent? Do they worry about diluting law's autonomous contribution to order by freighting it with other issues and considerations? "Positivists." Do they think of law more fluidly? Are they worried about values and context? Do they stress the dangers of a law that has drifted free of the real world? "Naturalists." Do they fall someplace in between? Is their instinct to split the difference? Do they stress pragmatism over principle? The "eclectic" or "Grotian" tradition. 
Some Conventional Schools of Thought About International Law

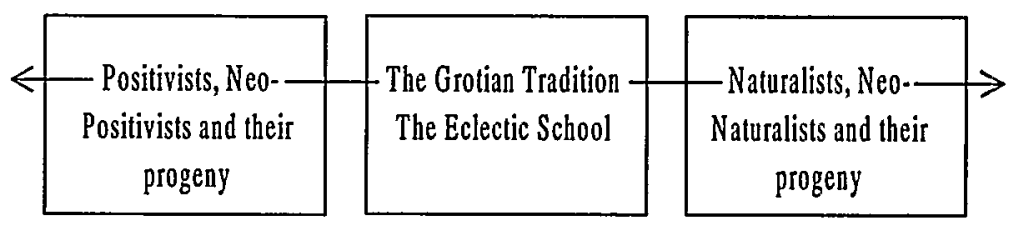

In traditional textbooks about international law, these schools of thought are often introduced by lists of ideas or propositions to which people in the schools are thought to adhere. It would be far more accurate to describe what it means to participate in a school of thought by focusing on a person's argumentative default position, his or her instinct in arguing about the field's central questions or basic doctrinal and institutional choices. A "positivist" will start off thinking about any of the choices we have looked at with more sympathy toward the left-hand pole, will tend to see anyone less "positivist" than himself or herself as making the errors of the right-hand pole. For a naturalist, the reverse. It is not surprising that as argument about these matters has gone on, more and more mainstream international lawyers resist identification as either positivists or naturalists, but see themselves instead as "Grotians," instinctively eclectic about all the choices we have looked at. Because all these "eclectics" continue to argue with one another by treating their opponent's position as if it implicated the dangers of an extreme that would give away the project of international law altogether, it is common to think that other people belong to schools of thought and argue from belief while one's own position reflects a sensible analysis of a specific and nuanced situation.

In each period of renewal and consensus, the field has been arranged in slightly different "schools of thought." During periods of disciplinary crisis, the goal of intellectual work is often to rearrange and restabilize the intellectual terrain, and the configuration of "schools of thought" is itself up for grabs. Prior to World War II, the U.S. international law academy thought itself roughly divided into positivist and naturalist schools of thought. These schools were differentiated by their tendency to argue from the formal law and sovereign autonomy poles (positivists) and from informal law and sovereign community poles (naturalists).

Schools of Thought in American International Law 1925-1939

\begin{tabular}{|c|c|}
\multicolumn{1}{c|}{ MAINSTREAM } & COUNTERPOINT \\
\cline { 2 - 2 } & Positivists \\
Sovereign autonomy & Naturalists \\
Formal law & $\begin{array}{r}\text { International community } \\
\text { PCIJ } \\
\text { International law }\end{array}$ \\
\end{tabular}

The consensus default during this entire period was to the left end of both primary spectrums. It is in this sense that we can call this the age of positivism in international law. There were also dissident voices urging a less formal, more embedded law as both a better expression of political reality and as an expression of a higher, more integrated international community. These voices were strongest in the anxious period just after World War I, when the discipline was most resolute in rejecting the legacy of the Hague system, which was perceived to have failed in 1914. They were often associated in the United States with political science rather than law, with progressive Wilsonianism, with support for the League of Nations, and with interest in international organizations more generally. They were also strong in the 
Catholic tradition. Although they faded from the mainstream after the establishment of the Permanent Court and disillusionment with the League, they remained present as a kind of ethical and political counterpoint.

After World War II, the terrain changed dramatically. All of prewar international law was in disrepute after 1945-positivists in the United States had largely been isolationist and the naturalist enthusiasts for the League seemed to have been altogether out of touch with the world of political possibility. Numerous efforts to criticize, reform, and renew the profession were launched in the late 1940s and 1950s. Only in the 1950s did a new consensus begin to emerge, which would last for more than thirty years.

In a sense, it is correct to say that after World War II everyone was an eclectic, far more flexible in bringing to bear arguments from across the spectrum on any given doctrinal or institutional choice. But there was also a wholesale reorganization of the main intellectual commitments defining "schools of thought" in the field. Beginning in the 1950s, most International lawyers in the United States rejected both naturalism and positivism in favor of a sensibility that was influenced by pragmatism, functionalism, American legal realism and the American legal process school. By 1960, the postwar generation of international lawyers and academics had established two new schools of thought-both of them postpositivist and postnaturalist-between which international lawyers in the United States then arranged themselves for a generation.

At one end of the new spectrum was the Yale School, dominated first by Harold Lasswell and then by Myres McDougal, and at the other the Columbia School, led by Louis Henkin and Oscar Schachter. Just as in the prewar discipline there was a positivist mainstream and a naturalist counterpoint, now the Columbia School became the mainstream and the Yale School became the counterpoint.

The Yale School situated itself toward the policy end of the formal/informal law spectrum and toward the sovereign autonomy end of the sovereign autonomy/international community spectrum. The Yale scholars worked self-consciously in the tradition of American legal realism and were most insistent in their critique of formalism-as practiced by both naturalists and positivists. They introduced the word policy into the international law vocabulary as an alternative to norms-a category of judgment and political management that stood outside hard and soft law, rules and principles. As they moved further toward the right side of the formal/antiformal axis, they were also acutely aware of scholars still further from legal form who had abandoned international law altogether for political science. They differentiated themselves from this new political science "realism" by stressing a commitment to order among sovereigns, to values and policies rather than to a Hobbesian individualism among states. By 1960, the Yale School represented a solid alternative that was neither positivist nor naturalist--it combined a strong antiformalism with an insistence on "realism" about sovereign autonomy as the basis for world community. Its adherents had broken the link between an antiformalism and prewar institutional idealism, as well as the link between sovereign autonomy and prewar formalism about norms.

At the same time, the Columbia School was moving in exactly the opposite direction. These scholars were also critical of prewar positivists-but for their emphasis on isolationism and sovereign autonomy, not for their commitment to norms. They were also postrealist scholars, and had a healthy skepticism about the solidity of codification. Their commitment to norms was one that celebrated principles as much as rules, soft law as much as hard, flexible interpretation as much as strict. For those in the Columbia School, the point was to build an international legal order focused on the institutions of the United Nations, to establish a normative fabric that could bridge the gap between East and West, and to establish a flexible institutional locus for decolonization and development in the Third World, outside the Cold War divisions. This search for a humanist neutralism required norms-human rights norms, procedural norms, administrative law. Too much policy could easily jeopardize the search for 
a community acceptable to East, West, and South.

By 1960, the Columbia scholars represented a clear alternative to the Yale School, one that was also neither positivist nor naturalist in the prewar sense. They combined a weak antiformalism with a commitment to neutral norms and humanist institutions as law for the modern international community. They had broken the link between a formal commitment to norms and the insistence on sovereign autonomy that had characterized prewar positivism. But they had also broken the link between a commitment to international community and the idealism of prewar progressives and naturalists. We might illustrate this transformation as follows:

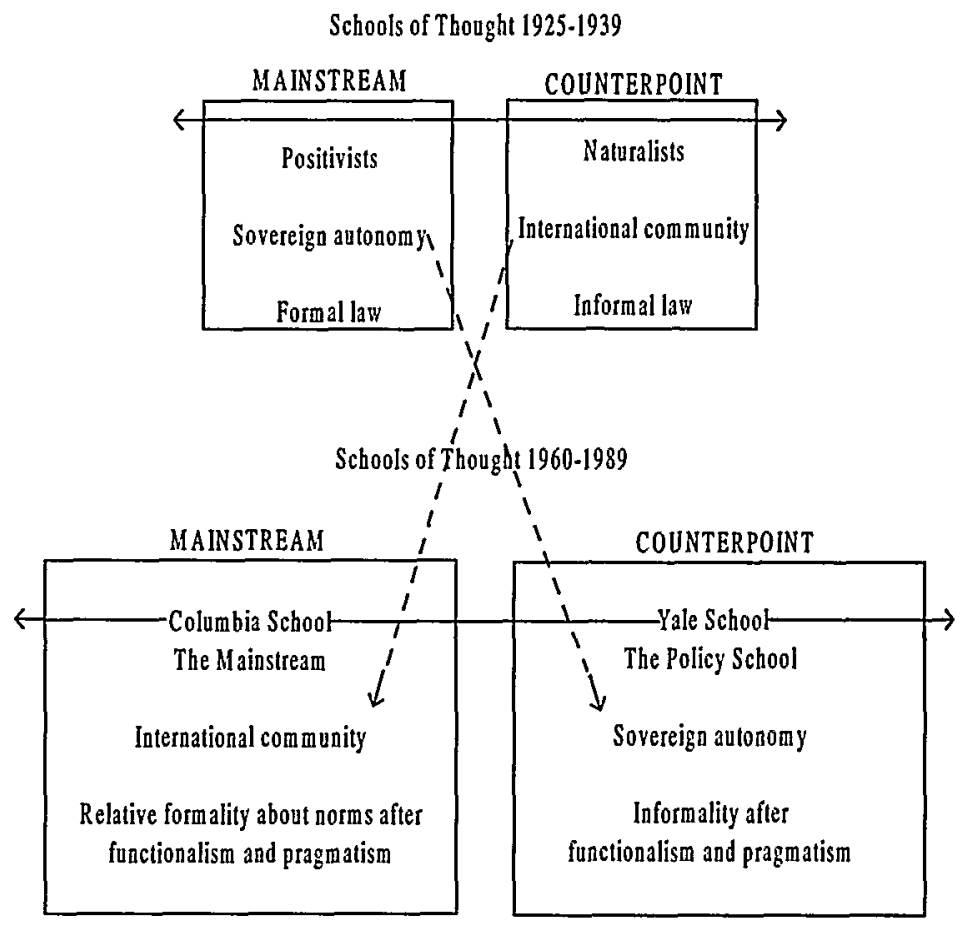

This new arrangement lasted more than thirty years, until the end of the Cold War in 1989. Since then, the field has been in a new period of anxiety and contestation. Early in this period of anxiety, there were fleeting efforts to revive the Yale School-symbol of a more flexible alternative to the disciplinary mainstream for a generation-just as there had been a variety of neonaturalist revivals in the 1940s. Most leading international lawyers under age fifty in the United States, however, are now critical of both the Columbia School and the Yale School.

The field has become a center for political and intellectual contestation. There are military voices, economic voices, populist voices, conservative voices, post-Marxist voices, feminists, queer theorists; scholars whose formation was powerfully inflected by the Lat/Crit movement, the Critical Legal Studies movement, by neoconservatism, and on and on. National differences are more pronounced-never has the United States international law tradition seemed as idiosyncratic, or been in such sustained methodological and political debate with international lawyers in other traditions. This Ninety-Fourth Annual Meeting, more than any other, has placed the ideological range within the field on display.

And yet, although a new disciplinary consensus has not yet emerged, there are strong proposals on the table, both for a new mainstream consensus and for a set of methodological counterpoints. Despite the presence of dissident voices among the field's established playerspeople like Allott, Berman, Carty, Charlesworth, Chimni, Chinkin, Engle, Frankenberg, Hernandez, Koskenniemi, Langille, Mutua, Onuma, Paul, Tarullo, Valdes-the beginnings of 
a new mainstream approach to the field are now visible, proposed largely by people in their forties under the rubrics of "transnational law," "the legal process," or "liberalism," terms they borrow from the scholarship of the last great period of anxiety in the 1950s.

These scholars, the leading "new" scholars of my generation-people like Koh, Slaughter, Alvarez, Kingsbury, Teson-many of them my law school classmates, friends and colleagues, urge movement toward a new understanding of international community and a new appreciation for an antiformalist international law. In the process, they reaffirm some of the field's most familiar and dogmatic propositions: that sovereignty has eroded, that international law should be understood politically, that the boundary between international and municipal law is porous, that International law may not be as universal as it pretends, that the international regime is better understood as a process or multilevel game than as government by legal norms. They have taken ideas that have been part of disciplinary common sense for a century - pragmatism, antiformalism, interdisciplinarity-and turned them into a fighting faith. This methodological self-confidence announces a political optimism: The end of the Cold War will complete the internationalist project, inaugurating a humanitarian "civil society": an "international community" that will dethrone the state, welcome wider participation, and open international law to the political.

The specific reform proposals on offer differ quite a bit-use domestic courts to enforce international norms, harmonize national regulations rather than seek international norms, use international law principles to energize a broad coalition of nongovernmental organizations rather than rulemaking by intergovernmental agencies, reimagine the international judiciary as a player in a social game whose currency is legitimation-but the forms in which they are presented are broadly similar. They urge greater disaggregation of international law, more reliance on national institutions, more blurring of the lines between law and politics, and between national and international law, than before. These new mainstream voices criticize the Columbia School for overstating the role of rules and insist on a revitalized antiformalism. At the same time, however, they criticize the Yale School for straying too close to Morgenthau's political science of autonomous sovereigns. The idea is to break the association between the community orientation of the Columbia School and its overemphasis on rules, while at the same time breaking the Yale association between antiformalism and sovereign autonomy.

As we might expect, these mainstream proposals have generated a set of counterpoints, again written within the discipline's historic lexicon of arguments. Counterpoints have proposed themselves on both the left and the right. Dissident voices of both types coalesce around an insistence on relatively more formal conceptions of law than the transnational-liberal-legal-process mainstream, and rather more skepticism about the possibility of an international community.

Relative to the centrist proponents of "transnational" and "liberal" law, the new counterpoint positions stress the formality of entitlements and the autonomy of actors. On the center-right this comes from "public choice" scholars, often working in the neighboring field of international economic law, who model the emergence of institutional regimes on the basis of game theories rooted in the autonomy of decision makers, and sympathetic to the possibility of a formal legal fabric. On the left, we find a variety of scholars rethinking the field from the perspective of one or another "identity politics." To get purchase against the emerging transnationalist mainstream, these scholars stress the relative stability of their identity positions - as women, as people of color, as Latin Americans, as gay and lesbian, indigenous or disabled people or as Third World nationals-as well as the relative formality of entitlements necessary for their protection. These voices respond both to the more extreme assertions of Third World sovereign autonomy and to assertions of cultural relativism which they fear would undermine their aspiration for universal human rights. These human rights enthusiasts have broken the link between relatively formal law and a universalist international community, and in that departed from even the Columbia School's mainstream enthusiasm for human rights. But they have also broken the link between a public order system based on the autonomy of actors and the antiformalism of the Yale School.

International lawyers in the United States are on the verge of rearranging the basic high- 
low arrangement of positions in their field for the second time since the end of World War II. We might chart this proposed reorientation of the field as follows:

Schools of Thought 1960-1989

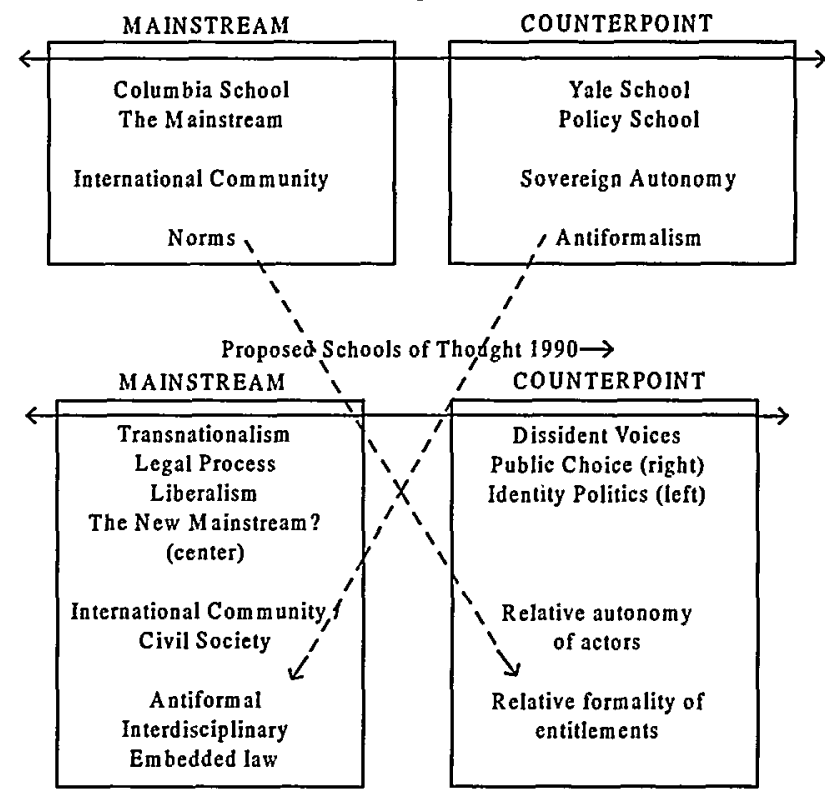

If we put these realignments together, we can trace changes in the disciplinary lexicon as successive generations rebuild the discipline's mainstream by rearranging central terms, borrowing from and criticizing earlier approaches from both the mainstream and the more dissident counterpoint, and focusing attention on different threats external to the field. Put together, the history looks like this:

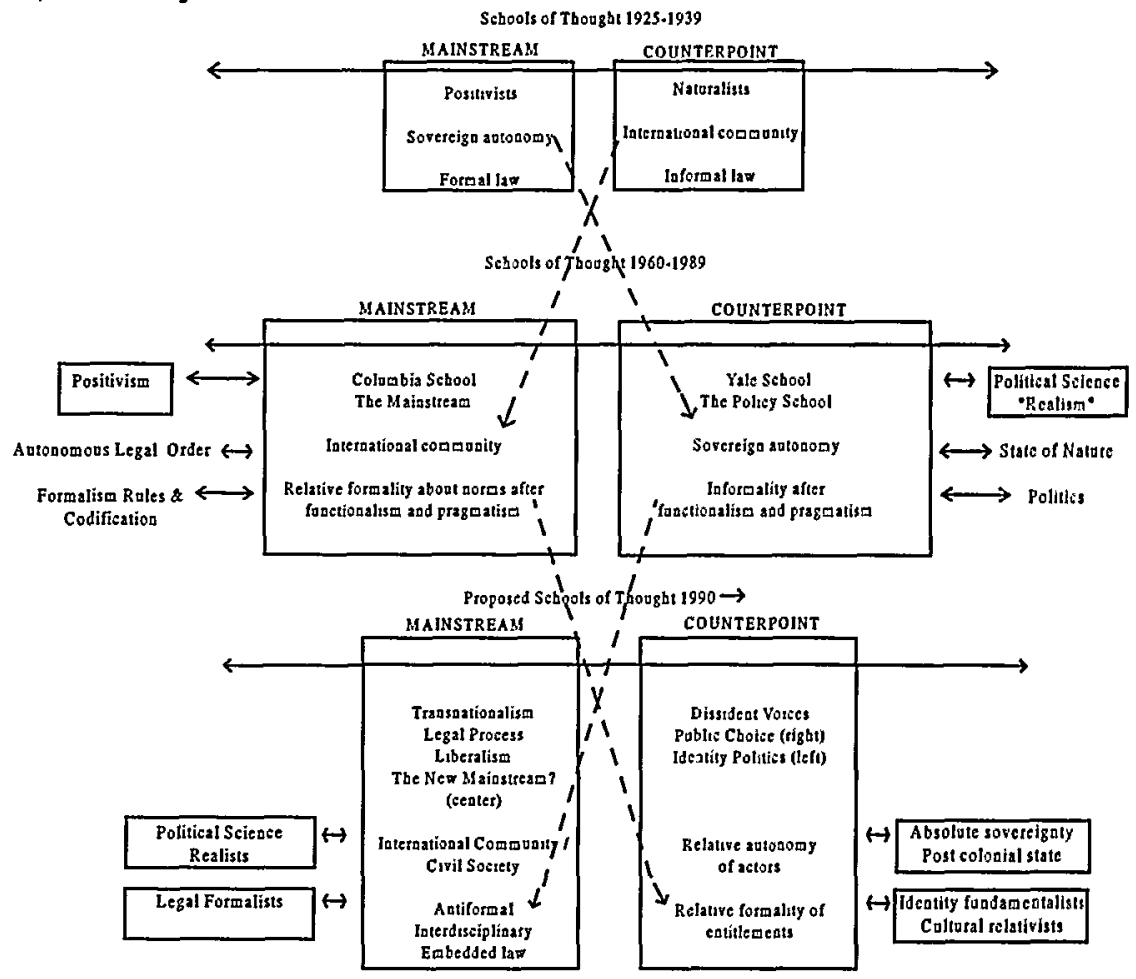




\section{SOME OPEN QUESTIONS}

An elementary map of the discipline's ambivalences and commitments like this leaves more questions open than it answers. We should wonder if this vocabulary limits the international law professional in any significant way. An astonishing range of different phenomena have been understood in these terms over the last hundred and more years, and the vocabulary seems repeatedly to renew itself in the face of a postwar anxiety about new political and economic realities. But do the discipline's own reform ideas capture the full range of the politically possible? How compulsory is debate in these terms? Can renewing the field mean something other than a reorganization of this vocabulary? Although there is now some excellent work addressing these questions, we need further research into the limits this vocabulary poses for the imagination.

It is also difficult to understand how this extremely plastic and repetitive professional vocabulary develops-why does one or another school of thought become the "mainstream," another only a "counterpoint"? Why does the arrangement of schools remain stable for long periods. and then rearrange itself so dramatically in only a few years? Why, we should wonder, does one or another set of ideas within this broad vocabulary come to dominate at a particular time, and what animates movement among these ideas? I have started to work on these further questions, but can only suggest some tentative answers here. To go further will require a more sociologically attuned mapping enterprise. The process by which a disciplinary vocabulary is used and transformed remains an extremely human one. Beyond the work of individuals responding to problems with good ideas, we have energy and passion which can better be understood in the language of power and group struggle.

It comes as no surprise that one set of ideas within a broad disciplinary vocabulary can come to dominate at a particular moment because people with that idea have institutional resources to devote to its implementation. If an American administration pumps money into international institutions to develop interest in the use of international law by national courts, or if a leading law school tenures scholars who are promoting interest in national courts, or if the American Society of International Law funds study of international law by national court judges. or if important journals have symposia on relations among national judiciaries in various countries-all this will have an effect on the perceived plausibility of these ideas. We are all familiar with the work of foundations-from the Ford Foundation in the 1960s to the Olin Foundation in the 1990s-inflecting the agenda of professional disciplines. The international law discipline has its own odd lot of institutions scattered about, often with some power to dispense jobs, fancy certificates, visas, medallions and the like. If the United Nations sponsors symposia on Third World approaches to international law, or the United Nations Educational, Scientific, and Cultural Organization publishes books on the subject, the plausibility of these ideas will be affected. If the author of such a book becomes president of the World Court, some people will read the book, some will reject it, others may try to repeat the gesture, others treat it as spent. The ideas about international law popular at a given moment in some countries are more influential than those popular in others simply because some countries are more powerful. The effects of educational patterns in the metropolis on thinking at the periphery are no less pronounced today than a hundred years ago.

Power in this sense-money, access to institutional resources, relationships to underlying patterns of hegemony, and influence-is central to the chance that a given idea will become influential or dominant within the international law profession. We need look no further than the extremely disproportionate effect of ideas developed in the United States since World War II. Struggle among individuals and groups over resources-institutional resources, prestige, the resources of perceived plausibility, disciplinary hegemony-and the processes by which these resources are in turn allocated are better explanations for the dominance of some ideas at some times, and for transformations in the disciplinary vocabulary, than either the good-faith 
pragmatism of innovative individuals or the meritocractic allocation of resources by practitioners and institutions external to the field.

To understand this struggle, we need a map of disciplinary groups parallel to our map of the disciplinary lexicon. As a starting point for such a mapping exercise, let me propose three basic sorts of group dynamics within the field of international law: those based on an affinity for ideas, those based on professional and personal identity, and those based on the struggle for domination.

\section{Common Intellectual Projects and Ideas: The Dynamic of Commitment and Aversion}

At the most overt level, many people in the field are animated by their fealty to a set of ideas. They do come to believe in the importance of various intellectual propositions-about law, about international society-and they then develop projects to promote these commitments. They try to get other people to share their ideas and forego competing ideas. And, of course, people come to believe that other ideas are not as valid or important or useful as their own, and they develop aversions to projects that seem to express commitments with which they disagree. As particular doctrinal or institutional projects come to be associated with one or another of these ideas, those who share the commitment can sometimes be mobilized on its behalf, just as those who do not can often be mobilized against it. Sometimes groups sharing intellectual commitments or aversions develop projects to promote these commitments. It is also common, however, for groups formed on the basis of a shared professional identity or political project to seek allies on the basis of these shared intellectual commitments.

The most important idea around which international lawyers have organized themselves has been the discipline's own broad mission - to construct governance among states, to speak to power from a cosmopolitan point of view, to promote a broadly liberal and rationalist frame for understanding international affairs. Of course, particular groups of international lawyers experience this commitment differently. A group could form around the project of ensuring that little in international law changes, or the idea that everything needed to be rethought in order for the discipline to survive. Each of the positions mapped in the professional lexicon has, also, at one time or another, been the basis for shared commitment and aversion among some international lawyers. Rearranging the field's schools of thought, proposing a new mainstream or counterpoint arrangement of the disciplinary vocabulary-these are projects of this type. Moreover, the discipline is intellectually and politically porous, so that international lawyers in different countries are influenced by the intellectual styles and political preoccupations of the national elites within which they work, and the long march of the tendencies operates in international law as elsewhere.

\section{Identity Groups: The Dynamic of Affiliation and Disaffiliation}

If we thought of a professional discipline simply as a group of people sharing a common vision, project or professional vocabulary, divided by intellectual orientations, commitments and aversions, we would miss a great deal. The profession is also riven with sociological and political affiliations that are not experienced first as intellectual commitments. The field is animated by the seductive power of groups and individuals, as well as by the desire of many professionals to disaffiliate with one or another group of colleagues. Affiliations based on personal and professional identity affect the distribution of ideas in the field as profoundly as do shared intellectual commitments.

We are all familiar with the charismatic power strong teachers or professional leaders can exert on behalf of their methodologies. People can also be attracted or repelled by doctrinal or institutional projects-building courts, working with nongovernmental organizations-because they express particular professional identities: people who build bridges, or like to argue, or always look on the bright side or like to feel that they are lighting a single candle. Some groups will seem "in" and some will seem "out" at particular moments. Some professional "voices" 
can seem more fun to speak with than others-more sophisticated, more daring, safer, more committed. more powerful, more abject. Maybe the Yale people have all the fun, or the Columbia people are the really serious ones, or the formalists exude the pleasures of negation.

Professionals are often more ready to affiliate with those who share their disciplinary subspecialties and to disaffiliate from those in other departments. Like other fields, international law is also divided by generational affinities, people who remember World War II, who worked in European reconstruction, who were affected by Vietnam, who grew up with computers and so forth. Among the strongest sources of professional identification are the links bult through mentoring relationships. Like ethnic, class, gender, race, religious, national or other strong identities within the broader political field, mentoring relationships present, at a microlevel, a somewhat independent field of life, of desire, affiliation and alliance between the rationalist community and the ambitious individual. In launching projects or proposing intellectual commitments, it goes without saying that it is often possible to find allies and enemies by tracing the links among mentees and mentors.

\section{Pursuing Projects: The Will to Dominance and Submission}

The discipline is more than groups of people with substantive commitments or professional identifications. The patterns of intellectual commitment and aversion, and of professional affiliation and disaffiliation, provide a context or terrain in which professionals can pursue projects of dominance and submission with other individuals and groups. New thinking emerge $\checkmark$ not simply as the result of a disinterested persuasion effort among identity constituencies in the field with different commitments-it is also the result of competition among constituencies inside and outside the field for authority, recognition, prestige, resources. Many such projects are simply the extension into action of an intellectual commitment or professional identity. Others express a will to power that arises outside these common professional characteristics. And the discipline has a will to power of its own, for itself as much as for its vision.

Moreover, although it is less often discussed in these terms, there is also a will to submit which will affect the distribution of ideas and resources in the discipline at any given time. The discipline as a whole may see itself paying fealty to other powers-to politics, say, or to economics. International lawyers may find congenial the role of servant to statecraft, voyeur of power. chronicler of politics, even powerless critic of power, and might be altogether uncomfortable thrust into the driver's seat. And individual international lawyers may seek out the leadership of others in the profession, regardless of the particular commitments or identifications their projects entail, for the experience of following.

International lawyers often seem to oscillate between a will to rule and abjection in the face of what they interpret as power. Looking back on the field over a century, the disciplinary will to disengage from power is striking. International lawyers coming into the field after 1980 , conversely often experienced their elders as having submitted far too happily to a kind of disciplinary detachment from the foreign policy apparatus. Opposition to this willed submission became a force of its own, producing an intense energy to perform as macho and entitled to rule.

International lawyers participate in a range of political projects outside the field of international law on the basis of their expertise and seek allies in the profession for these efforts. Such projects can be associated with the broad party politics of the society. International lawyers in the United States have been active in supporting both the Democratic and Republican parties, as well as in promoting particular factions within them-Rockefeller Republicans, Stevenson Democrats and so on. If we look at international law in the United States, it might make more sense to organize it in terms of the political affiliations of its members than in terms of either its internal professional associations or intellectual commitments. At the moment, American international lawyers on the right tend to be formalists about American sovereign prerogatives and strict interpreters of the commitments of foreign powers, particularly to respect property rights and the prerogatives of international institutions, but very expansive and 
policy oriented when it comes to interpreting restrictions on U.S. power abroad. American international lawyers on the left are more likely to be rule oriented when it comes to American obligations and far less worried about the formalities of multilateral or international institutional initiatives. Political affiliations of this type contribute to the argumentative instability of the profession's intellectual terrain, and to the general sense that everyone is an eclectic or postintellectual pragmatist. Political efforts of all these types will influence the distribution of ideas and professional affiliations within the discipline.

\section{Commitment, Affiliation, Domination and the Distribution of Ideas}

In mapping the influence of power on the distribution of ideas in a field, it can be helpful to separate these three dimensions-commitment, identification, domination-for they can operate independently of one another. In the simple case, a person who seeks to make a project out of promoting international law seeks allies among those who share an intellectual commitment to this idea, and who share professional identifications of one or another sort with others in the field. He or she then seeks to dominate those within and without the field who are less enthusiastic about this project.

But we can easily imagine more complex cases. A person might seek to translate his or her commitment to an intellectual proposition-building courts is better than building administrative agencies-into action as a project by seeking the support of others with whom he or she shares other commitments or identifications. A person or group might seek power by transforming its professional identity-say, those who know about defense policy or appreciate political science-into an intellectual commitment for the field as a whole, and so on.

We are now in a position to supplement the traditional account of the distribution of ideas in the discipline which focuses rather exclusively on their usefulness. We began with the constraints of the professional lexicon itself, its tendency to hyperbole and sectarianism, its blind spots and biases, the language within which professionals pursue projects. Professionals also embellish and transform the discipline's basic arguments in the pursuit of projects, for which they seek allies and resources. We might think of the discipline as a kind of force field animated by some combination of these three elements:

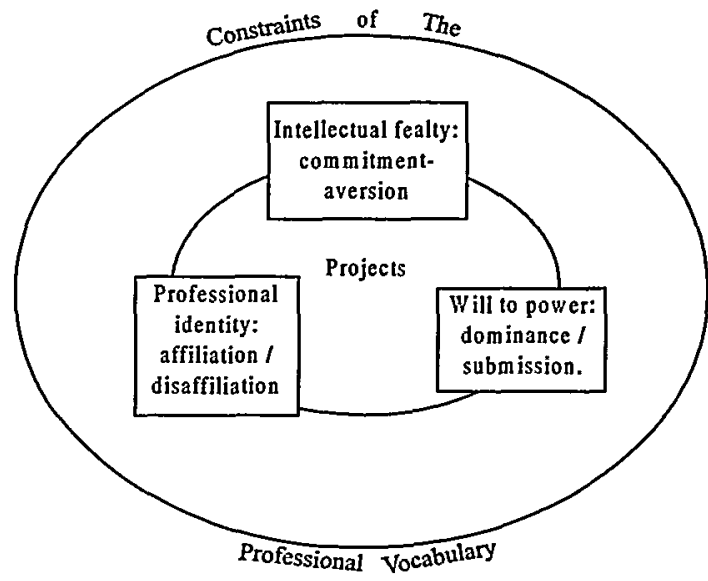

There is a common disciplinary mission, viewpoint and vocabulary. International lawyers share a range of commitments and aversions to particular intellectual propositions within that vocabulary. They affiliate and disaffiliate from a variety of professional identities, some expressing commitments of the field, others provided by the context of their work or their broader social context. Lawyers pursue projects, efforts to promote intellectual, political or personal objectives, deploying their expertise in the discipline's vocabulary, seeking alliances 
with others on the basis of shared commitments, aversions, or affiliations. The status of forces among particular ideas, particular modes of criticism or reform, will often depend on the distribution of forces among groups whose projects, commitments, and affiliations seem implicated.

That is far enough to take the story today. I am convinced that the two sorts of maps I have suggested here-a map of the professional lexicon and a rudimentary map of the influences on its transformation through time - can be helpful in understanding how one idea comes to dominate at one moment rather than another-although, of course, they would need much further and more nuanced development. But having such maps, we could begin to ask about the limitations-blind spots, biases, professional deformations-that disciplinary expertise imposes on those who wield it.

I am less sure that maps of this sort can be of much help in navigating outside the constraints of the professional vocabulary. The intense ambivalence and flexibility of the scheme makes it hard to imagine we will be able to escape professional limitations, supposing that we want to, simply by reversing these conventional commitments. People have tried to develop extravernacular projects-I have brought along a bibliography of work that seems interesting and suggestive to me. In my experience, however, extravernacular projects that resist this lexicon, which glimpse around its boundaries in various ways, seem to need to be performed, to happen, to be staged. We have a map, if a rudimentary one, of disciplinary renewal. If you seek to improve and update the ambivalent vocabulary with which international lawyers argue hyperbolically for modest reforms, we know where to send you. But new thinking, thinking outside the box ... for that, so far about all we can say is that sometimes we know it when we hear it. 